\title{
Nutrition Supplementation Practices of Recreational Gym Users in Uganda's Capital City: A Cross Sectional Study
}

Haruna Muwonge ( $\square$ harunamuwonge@gmail.com )

Makerere University, College of Health Sciences

Timothy Makubuya

University of Missouri-St. Louis

Samuel K. Lubega

University of Cape Town

Robert Zavuga

Uganda Peoples Defence Forces

Roland S. Mukana

Kyambogo University

\section{Research Article}

Keywords: Nutritional supplements, athletes, gym users, athletes, dietary supplements

Posted Date: November 1st, 2021

DOI: https://doi.org/10.21203/rs.3.rs-993739/v1

License: (c) (1) This work is licensed under a Creative Commons Attribution 4.0 International License. Read Full License 


\title{
Nutrition Supplementation Practices of Recreational Gym Users in Uganda's Capital city: A Cross Sectional Study
}

\author{
Haruna Muwonge $^{1 * \bullet}$, Timothy Makubuya ${ }^{2 \bullet}$, Samuel K. Lubega ${ }^{3}$, Robert Zavuga ${ }^{4}$, \\ Roland S. Mukana 5 . \\ *Corresponding Author \\ ๑ These authors contributed equally to this work
}

1. Haruna Muwonge, MBCHB, Ph.D. *

Lecturer

Department of Physiology, College of Health Sciences,

Makerere University

P. O Box 7072, Kampala

Email: harunamuwonge@gmail.com

Tel: +256-784574544

2. Timothy Makubuya, Ph.D.

Assistant Professor

Department of Educator Preparation \& Leadership

College of Education

University of Missouri- St. Louis

364 Marillac Hall

1 University Blvd, St. Louis, MO 63121

Email: makubuyat@umsl.edu

Tel: +1314-516-7311

3. Samuel K. Lubega, Ph.D.

Research Fellow

Division of Exercise Science and Sports Medicine

Department of Human Biology

Sports Science Institute of South Africa 
University of Cape Town

Email: 1bgsam001@myuct.ac.za

Tel: +27719534617

4. Robert Zavuga, BDS, MPH

Director of HIV/AIDS clinical research,

Uganda Peoples Defence Forces (UPDF).

Email: drzavuga@gmail.com

Tel: +256-772-655-723

5. Roland S. Mukana, Ph.D.

Senior Lecturer

Department of Sports Sciences

Faculty of Science

Kyambogo University

Email: rmukana@kyu.ac.ug mukanas2003@gmail.com

Tel: +256-776-098-555 


\begin{abstract}
Background: This study focused on investigating the prevalence of nutritional supplement (NS) usage, establishing their source and the motivating factors for the usage of NS among Gym users in Kampala city, Uganda.
\end{abstract}

Methods: The study employed a cross-sectional research design. Multistage random sampling techniques were used to select 45 gym users among the 5 divisions that constitute Kampala city. Data were collected using questionnaires and analyzed using SPSS Version 26, where means, $\mathrm{SD}$, frequencies and percentages were obtained. Chi-square tests were used for categorical comparisons between variables.

Results: The results showed that there were more male participants $(62.2 \%)$ than female participants (37.8\%). The majority (76.9\%) of gym users obtained NS from retail stores such as pharmacies, (10.2\%) from their sports coaches, (7.7\%) nutritionists/dieticians, and (5.1\%) from team mates. Non-professional gym users (62.3\%) reported higher levels of energy drink consumption than professional gym users (26.7\%). The consumption of vitamins, herbal products and proteins was also considerably high. We also identified coaches/trainers (30.8\%) as the main source of information, followed by nutritionists/dieticians $(23.1 \%)$ and online websites (20.5\%). Most gym users strongly agreed that supplements increase endurance training, increase strength, and make one healthier.

Conclusions: The prevalence of nutritional supplement usage among gym users was high, with energy drinks and herbal products being the most preferred supplements.

Keywords: Nutritional supplements, athletes, gym users, athletes, dietary supplements. 


\section{Introduction}

Uganda, a landlocked country in the eastern region of Africa, has an estimated population of 45 million, with a population of approximately 4 million people flocking Kampala capital city during the day. ${ }^{1}$ Although faced with the challenge of not having a sea port for easy exportation and importation, various medicinal products easily find their way to different marketing outlets in Kampala city through neighboring countries, especially Kenya and Tanzania. Among these are sports nutrition-related products that have flooded Kampala and have been linked to successful sports figures in Uganda. ${ }^{2}$ A recent report indicated challenges in reporting, tracking and identifying poor-quality medical products in Uganda. ${ }^{3}$ However, such products may include various types of nonlocally made NS.

It is important to understand that the consumption of foods in diets that do not necessarily meet the Recommended Dietary Allowance (RDA) is grounds for the legitimate consumption of additional foods that are widely referred to as nutritional supplements. ${ }^{4}$ These nutritional supplements (NS) contain food components that might provide more than one or more food nutrients. ${ }^{5}$ Furthermore, the recommendations for usage of NS are clear and suggest usage only among those individuals with restricted diets, those with severe weight loss and those that consume high quantities of one food group. ${ }^{6}$ However, as an increasing number of people purchase NS, more of those products continue to flock the market due to the increasing interest among users. ${ }^{2}$

Among recreational athletes in Greece, low levels of awareness and lack of information have been previously highlighted as a challenge. ${ }^{7}$ A previous self-reported study on the usage of NS among professional athletes in Uganda found that although the level of usage was low, there was a need to further sensitize frequent users. ${ }^{8}$ The literature on NS usage among gym users 
globally is still scant, with these few studies concentrated in developed countries. ${ }^{9-12}$ There is an increased influx of recreation centers or gyms in Kampala city of Uganda, leading to the continued demand for NS. The misuse of these products is concerning, particularly arising from high dosage and mixed usage. ${ }^{13}$ Therefore, the aim of this study was to assess the prevalence of nutrition supplement usage among gym users, sources of supplements and related information, and understand the perceptions and motivating factors for NS usage in an effort to design a community-based education awareness campaign for the public in Kampala city.

\section{Methods}

\subsection{Design}

The study used a cross-sectional design with a convenient sample involving gym users in selected gyms in the five divisions (Rubaga, Central, Nakawa, Makindye and Kawempe) of Kampala city in Uganda in 2019.

\subsection{Population}

A sample of 45 recreational gym users was enrolled in the study. We utilized a multistage sampling technique where gyms were eliminated based on their proximity to each other. In the first stage, gyms that were excluded were those that were in close proximity to each other. We instituted a fixed distance of approximately a 5-mile radius between the selected gyms as a way to increase the spread. A total of two gyms in each of the five divisions of Kampala were then randomly selected. In the second stage, adults in the selected gym $(n=45)$ were randomly approached and enrolled in the study. For one to be included in this study, they had to be > 18 years of age. All participants in this study consented to voluntary participation and were free to terminate participation at any time. The study was conducted according to the principles of the Helsinki Declaration and was approved by the Institutional Review Board of University of 
Missouri- St. Louis, the School of Biomedical Sciences in the College of Health Sciences at Makerere University in Kampala Uganda. This study was also registered and approved by the Uganda National Council for Science and Technology, IRB\# SS 5026.

\subsection{Instrument}

This study utilized a modified questionnaire from the original questionnaire designed by the

researchers. ${ }^{8}$ This study's questionnaire consisted of various sections. The first section captured responses to questions relating to an individual's sociodemographic factors such as age, gender and level of education. The second section was designed to solicit the respondent's motivating factors for using supplements. The third section gathered information on the sources of the utilized supplements and sources of supplemental information.

\subsection{Data Collection}

Prior to conducting the data collection, the researchers conducted two trainings for three research assistants at Makerere University in Kampala. The first training reviewed human participant protocols and usage of data capture forms. The second training equipped them on how to review and interpret the survey in local language and how to securely protect the consent and survey forms. Research assistants distributed surveys and collected data at gyms and post respondent workout sessions. Nine respondents were conveniently selected at each of the five selected gyms in the five regions of Kampala city.

\subsection{Statistical Analysis}

Data were entered and analyzed using SPSS 26.0 software for Windows. Continuous variables were summarized using means and standard deviations after assessing the normality of the data. We standardized our variables and tested the normality of our data using Lillieforts corrections and Kolmogorov_Smirnov tests. Categorical variables were summarized using frequencies and 
percentages. Chi-square tests were used to compare categorical variables between groups. A probability $p$ value $<0.05$ at a $95 \%$ confidence interval was considered significant.

\section{Results}

\subsection{Participant characteristics}

A total of 45 recreation gym users (male; $62.2 \%$, female; $37.8 \%$ ) in five subdivisions of Kampala city in Uganda participated in this study. Participant characteristics are provided in table 1. In terms of age groups, the majority of the participants (26.6\%) were within 20-25 years of age compared to the least number of participants from the 35 years and above age group (13.3\%). There was a significant difference $(P=.004)$ in users' education levels, with the majority of participants (27.9\%) having had some secondary school education and the least education level being nursery school (2.3\%). It was evident from the participant responses that fewer gym users in Kampala were current students (4.4\%), business managers (11.1\%), unemployed (11.1\%), skilled agriculturalists (15.6\%), or professional workers (17.8\%) compared to the majority who engaged in a variety of other professions (40\%). These occupational group differences were, however, not significant $(P=0.126)$. The majority of recreation gym users were professional users $(51.1 \%)$ compared to their nonprofessional counterparts (48.9\%). These male and female participants also engaged in a number of sports: football/soccer (2.2\%), netball (4.4\%), athletics (6.7\%), and weightlifting (40\%). A significant number of participants (46.7\%) did not indicate any sports participation $(P=.017)$. 
Table 1. Characteristics of participants

\begin{tabular}{|c|c|c|c|}
\hline Variable & Frequency (n) & Percentage $(\%)$ & $P$ value \\
\hline $\begin{array}{l}\text { Usage of Nutrition Supplements } \\
\text { Yes } \\
\text { No }\end{array}$ & $\begin{array}{r}39 \\
6\end{array}$ & $\begin{array}{l}86.7 \\
13.3\end{array}$ & $.005^{*}$ \\
\hline $\begin{array}{l}\text { Age group }(\mathrm{n}=45) \\
18-20 \text { years } \\
21-25 \text { years } \\
26-30 \text { years } \\
31-35 \text { years } \\
36 \text { years and above }\end{array}$ & $\begin{array}{r}9 \\
12 \\
10 \\
8 \\
6\end{array}$ & $\begin{array}{l}20.0 \\
26.6 \\
22.2 \\
17.8 \\
13.3\end{array}$ & $.001 *$ \\
\hline $\begin{array}{l}\text { Sex }(n=45) \\
\quad \text { Female } \\
\text { Male }\end{array}$ & $\begin{array}{l}17 \\
28\end{array}$ & $\begin{array}{l}37.8 \\
62.2\end{array}$ & $.002 *$ \\
\hline $\begin{array}{l}\text { Highest Education level }(\mathrm{n}=43) \\
\text { Nursery school } \\
\text { Some primary school } \\
\text { Primary school } \\
\text { Some secondary school } \\
\text { Ordinary Level } \\
\text { Advanced Level } \\
\text { Tertiary Institution }\end{array}$ & $\begin{array}{r}1 \\
9 \\
6 \\
12 \\
3 \\
8 \\
5\end{array}$ & $\begin{array}{c}2.3 \\
20.9 \\
13.9 \\
27.9 \\
6.9 \\
18.6 \\
11.6\end{array}$ & $.004 *$ \\
\hline $\begin{array}{l}\text { Occupation } \\
\text { Student } \\
\text { Business manager } \\
\text { Professional } \\
\text { Skilled agriculture } \\
\text { Unemployed } \\
\text { Other professions }\end{array}$ & $\begin{array}{c}2 \\
5 \\
8 \\
7 \\
5 \\
18\end{array}$ & $\begin{array}{l}4.4 \\
11.1 \\
17.8 \\
15.6 \\
11.1 \\
40.0\end{array}$ & .126 \\
\hline $\begin{array}{l}\text { Type of gym user } \\
\text { professional user } \\
\text { non-professional user }\end{array}$ & $\begin{array}{l}23 \\
22\end{array}$ & $\begin{array}{l}51.1 \\
48.9\end{array}$ & $.003^{*}$ \\
\hline $\begin{array}{l}\text { Sport played } \\
\text { Netball } \\
\text { Football/Soccer } \\
\text { Athletics } \\
\text { Weightlifting } \\
\text { None }\end{array}$ & $\begin{array}{r}2 \\
1 \\
3 \\
18 \\
21\end{array}$ & $\begin{array}{c}4.4 \\
2.2 \\
6.7 \\
40.0 \\
46.7\end{array}$ & $.017^{*}$ \\
\hline
\end{tabular}

${ }^{*} p<.05$ 


\subsection{Source of nutrition supplement}

When we asked the participants about the sources of their NS, the majority (76.9\%) indicated retail stores such as pharmacies (figure 1). Other sources of NS were sports coaches (10.2\%), nutritionists and dieticians (7.7\%), and teammates (5.1\%).

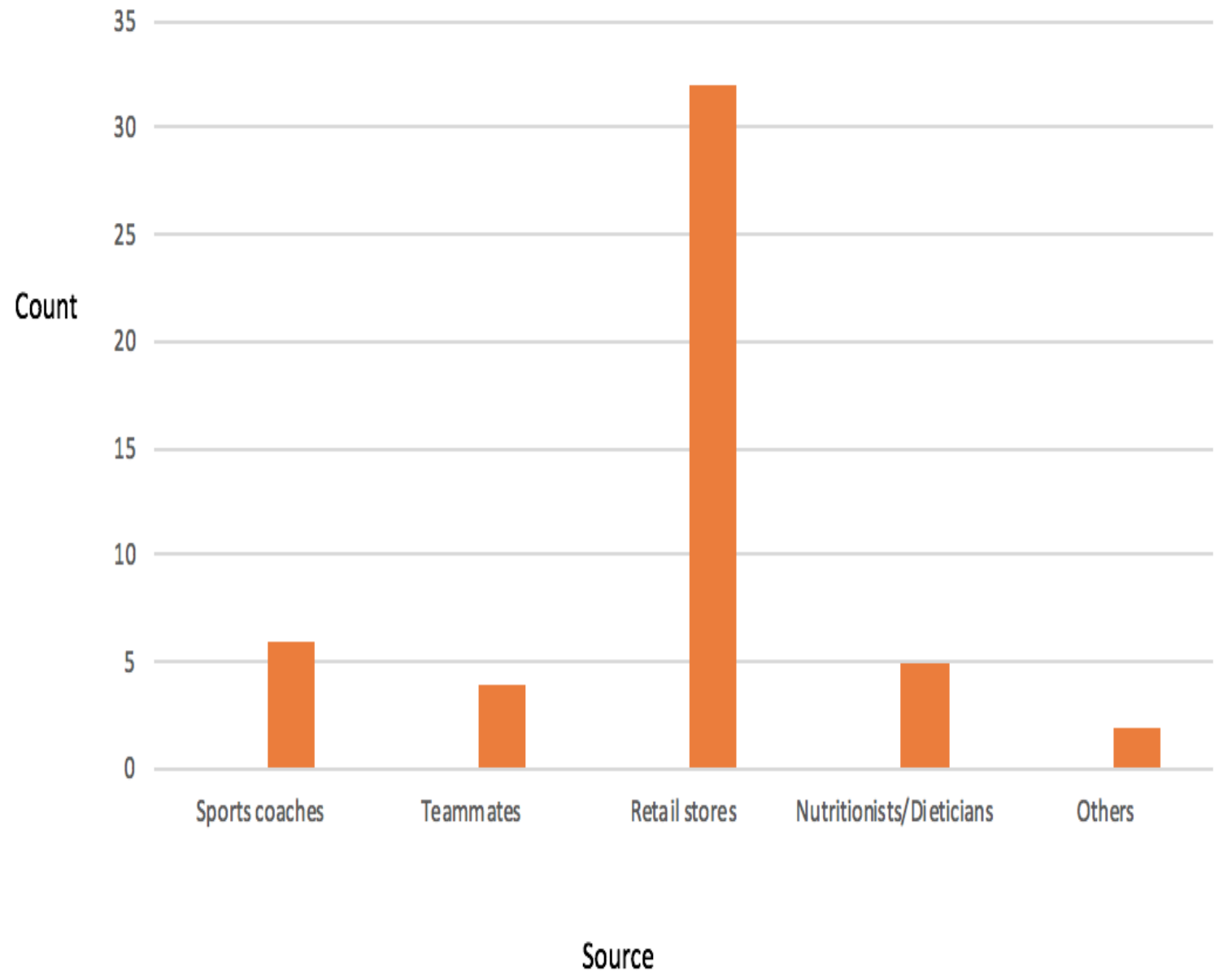

Figure 1: Source of NSs for recreation gym user participants in Kampala. This figure illustrates a variety of sources that participants reported as reliable avenues on the various products they consume. Individuals regard these as both valid and reliable sources of supplement effectiveness and any potential effects. Some participants indicated relying on more than just one source. 
Table 2 details the gendered categorization of NS sources for recreation gym users. Male participants were more likely to acquire NS from retail stores or pharmacies $(2.04 \pm .012)$ than female participants $(1.72 \pm .008)$. In terms of the source of NS, male participants who acknowledged using NS were more likely to acquire NS from their coaches $(1.98 \pm .016)$ than female participants $(1.33 \pm .025)$. However, female participants were more likely to acquire NS from nutritionists or dieticians $(1.44 \pm .011)$ than their male counterparts $(1.32 \pm .006)$.

Furthermore, the female participants were more likely to obtain NS from teammates $(1.16 \pm .040)$ than their male counterparts $(1.06 \pm .004)$.

Table 2. Source of nutrition supplement by gender of gym user

\begin{tabular}{|l|cc|lc|}
\hline Source of Nutrition Supplements & \multicolumn{2}{|c|}{ Females } & \multicolumn{2}{c|}{ Males } \\
\hline & Mean & SD & Mean & SD \\
\hline Coach & 1.33 & \pm .025 & 1.98 & \pm .016 \\
\hline Teammates & 1.16 & \pm .040 & 1.06 & \pm .004 \\
\hline Retail store or pharmacy & 1.72 & \pm .008 & 2.04 & \pm .012 \\
\hline Nutritionist or dietician & 1.44 & \pm .011 & 1.32 & \pm .006 \\
\hline Others & 1.10 & \pm .008 & 1.11 & \pm .010 \\
\hline
\end{tabular}

Note. SD is standard deviation

Figure 2 indicates the various types of NSs consumed by gym users. Overall, energy drinks and herbal supplements were the most commonly consumed types of NS. The majority of male gym users indicated a preference for energy drinks (23.1\%), followed by herbal supplements (12.8\%), whereas female gym users indicated a higher preference for energy drinks (10.3\%) and herbal supplements $(10.3 \%)$ 


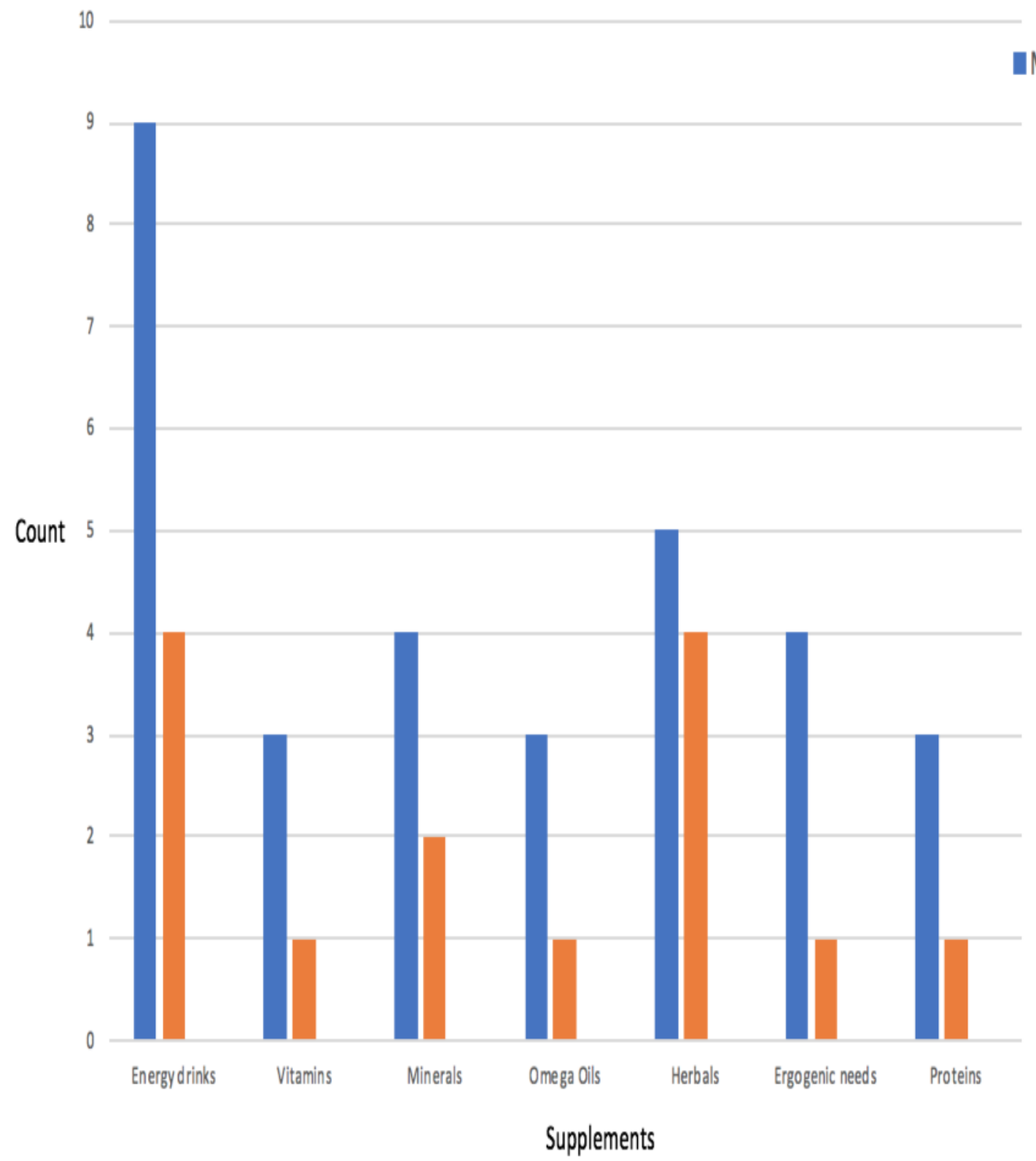

Figure 2: Various types of NSs among male and female gym users. This figure illustrates the various types of supplements that participants reported utilizing routinely to support their exercise regimen in gyms in Kampala. Some participants indicated using more than one type of supplement. 


\subsection{Professional versus Non-Professional gym user consumption}

As indicated in Table 3, non-professional gym users reported the highest levels of energy drink consumption compared to professional gym users. (professional $=26.7 \%$, nonprofessional $=$ $\left.62.2 \%, \chi^{2}=15.93, \mathrm{df}=1, p<.001\right)$. The consumption of vitamins was also considerably high (professional $=26.7 \%$, nonprofessional $=40 \%, \chi^{2}=13.42, \mathrm{df}=1, p<.001$ ) in this group. The consumption of herbal supplements was considerably different between professional and nonprofessional gym users (professional $=4.4 \%$, nonprofessional $=46.7 \%, \chi^{2}=8.37, \mathrm{df}=1, p$ <.001). Protein consumption was also different between the groups, with higher consumption among professional users (professional $=22.2 \%$, nonprofessional $=6.7 \%, \chi^{2}=11.44, \mathrm{df}=1, p$ $<.001)$

Table 3. Supplement consumption patterns between professional and recreational gym users

\begin{tabular}{|l|r|r|r|r|c|}
\hline \multirow{2}{*}{$\begin{array}{l}\text { Type of gym user } \\
\text { Type of supplement } \\
\text { used (ALL) }\end{array}$} & \multicolumn{2}{|c|}{ Professional } & \multicolumn{2}{c|}{ Non-professional } & Chi- square \\
\cline { 2 - 6 } & Yes, n (\%) & NO, n (\%) & Yes, n (\%) & NO, n (\%) & $\chi^{2}$ \\
\hline Energy drink & $12(26.7)$ & $0(0)$ & $28(62.2)$ & $5(11.1)$ & $15.93 * *$ \\
\hline Vitamins & $12(26.7)$ & $0(0)$ & $18(40.0)$ & $16(35.6)$ & $13.42^{* *}$ \\
\hline Minerals & $4(8.9)$ & $8(17.8)$ & $12(26.7)$ & $21(46.7)$ & $5.62 *$ \\
\hline Omega oils & $1(2.2)$ & $11(24.4)$ & $8(17.8)$ & $25(55.6)$ & $4.99 *$ \\
\hline Herbals & $2(4.4)$ & $10(22.2)$ & $21(46.7)$ & $12(26.7)$ & $8.37^{*}$ \\
\hline Ergogenic needs & $3(6.7)$ & $9(20.0)$ & $9(20.0)$ & $24(53.3)$ & $2.37 *$ \\
\hline Proteins & $10(22.2)$ & $2(4.4)$ & $3(6.7)$ & $30(66.7)$ & $11.44^{* *}$ \\
\hline
\end{tabular}

$* \mathrm{df}=1, p<.05, * * \mathrm{df}=1, p<.001$ 


\subsection{Source of Supplements Information}

Recreation gym users indicated obtaining what they considered to be relevant NS information from coaches or trainers, nutritionists or dieticians, teammates, online websites, physicians or doctors, magazines or books and other sources that were not specified. The majority of participants (30.8\%) indicated coaches or trainers as a reliable source of information, followed by nutritionists/dieticians (23.1\%) and online websites (20.5\%). Physicians/doctors, teammates and magazines or books were indicated among other sources. (Figure 3). 
14

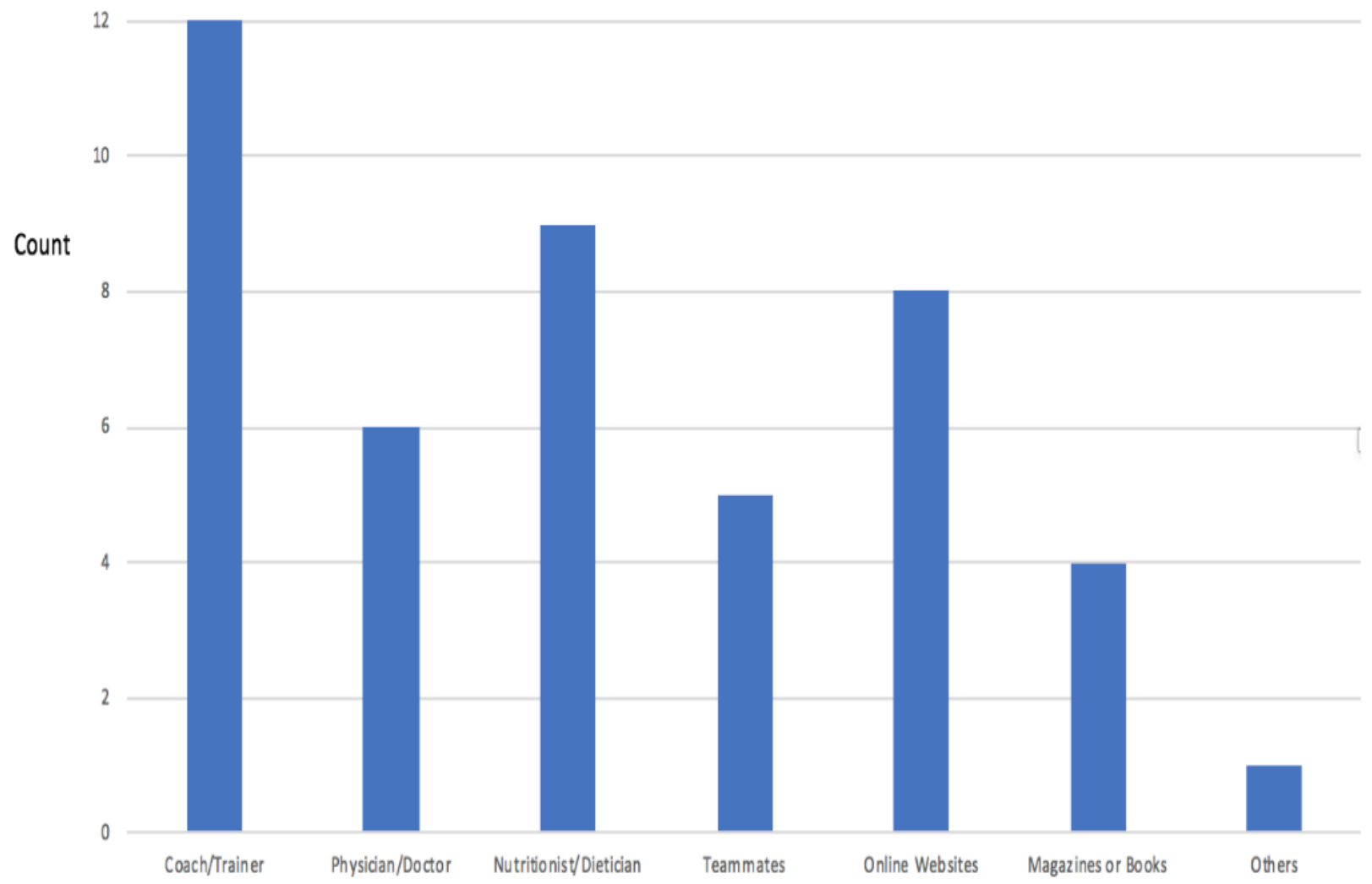

Source of Information

Figure 3. Various sources of information on NSs reported by gym users in Kampala city Uganda. This illustration includes sources of information that individual participants regard as both valid and reliable sources on supplement information and an avenue for information on product effectiveness and any potential side effects.

\subsection{Gym users' perceptions about supplement usage}

Using the Nutritional Supplement Perception Scale (NSPS), a modified version of the

Performance Enhancement Attitudes Scale (PEAS), ${ }^{13,8}$ gym users were asked for their views on various statements regarding NS. Their Likert-scale measured responses ranged from strongly 
disagree to strongly agree. Descriptive statistics in the form of frequencies and percentages of the different responses are captured in Table 4. In general, these responses showed variations in gym users' perceptions regarding NS. Most gym users strongly agreed that supplements increase endurance during training, increase strength, and make one healthier. In contrast, most gym users strongly disagreed on the statement that NS may contain doping agents (Table 4).

Table 4. Gym Users perceptions about nutrition supplements

\begin{tabular}{|c|c|c|c|c|c|c|}
\hline $\begin{array}{l}\text { How strongly do you agree or } \\
\text { disagree with the following } \\
\text { statements? }\end{array}$ & $\begin{array}{l}\text { Strongly } \\
\text { disagree } \\
\mathrm{n}(\%)\end{array}$ & $\begin{array}{l}\text { Disagree } \\
\mathrm{n}(\%)\end{array}$ & $\begin{array}{l}\text { Slightly } \\
\text { disagree } \\
\mathrm{n}(\%)\end{array}$ & $\begin{array}{l}\text { Slightly } \\
\text { agree } \\
\text { n }(\%)\end{array}$ & $\begin{array}{l}\text { Agree } \\
\mathrm{n}(\%)\end{array}$ & $\begin{array}{l}\text { Strongly agree } \\
\mathrm{n}(\%)\end{array}$ \\
\hline $\begin{array}{l}\text { 1. Nutrition supplements make me } \\
\text { healthier }(\mathrm{n}=45)^{*}\end{array}$ & $3(6.7)$ & $2(4.4)$ & $0(0)$ & $2(4.4)$ & $19(42.2)$ & $19(42.2)$ \\
\hline $\begin{array}{l}\text { 2. Nutrition supplements improve } \\
\text { my endurance } \quad(\mathrm{n}=42)^{*}\end{array}$ & $1(2.4)$ & $6(14.3)$ & $2(4.8)$ & $3(7.1)$ & $12(28.6)$ & $18(42.8)$ \\
\hline $\begin{array}{l}\text { 3. Nutrition supplements are safe to } \\
\text { use }(n=41)^{*}\end{array}$ & $1(2.4)$ & $3(7.3)$ & $3(7.3)$ & $13(31.7)$ & $15(36.6)$ & $6(14.6)$ \\
\hline $\begin{array}{l}\text { 4. Nutrition supplements provide me } \\
\text { with more energy }(n=44)^{*}\end{array}$ & $2(4.5)$ & $0(0)$ & $1(2.3)$ & $4(9.1)$ & $19(43.2)$ & $18(40.9)$ \\
\hline $\begin{array}{l}\text { 5. Nutrition supplements increase } \\
\text { the amount of training I can undergo } \\
(\mathrm{n}=43)^{*}\end{array}$ & $2(4.6)$ & $1(2.3)$ & $1(2.3)$ & $9(20.9)$ & $10(23.3)$ & $20(46.5)$ \\
\hline $\begin{array}{l}\text { 6. Nutrition supplements increase } \\
\text { my strength }(\mathrm{n}=42)^{*}\end{array}$ & $3(7.1)$ & $0(0)$ & $0(0)$ & $4(9.5)$ & $17(4.0)$ & $18(42.9)$ \\
\hline $\begin{array}{l}\text { 7. Nutrition supplements increase } \\
\text { my ability to cope with pain }(n= \\
40)^{*}\end{array}$ & $4(9.8)$ & $5(12.2)$ & $3(7.3)$ & $6(14.6)$ & $12(29.3)$ & $10(24.4)$ \\
\hline $\begin{array}{l}\text { 8. Nutrition supplements improve } \\
\text { my concentration } \quad(n=40) *\end{array}$ & $5(11.4)$ & $5(11.4)$ & $2(4.5)$ & $10(22.7)$ & $14(31.8)$ & $4(9.1)$ \\
\hline $\begin{array}{l}\text { 9. Nutrition supplements may } \\
\text { contain doping agents }(\mathrm{n}=40)^{*}\end{array}$ & $10(25)$ & $5(12.5)$ & $5(12.5)$ & $12(30)$ & $8(20)$ & $0(0)$ \\
\hline $\begin{array}{l}\text { 10. Recreational drugs give the } \\
\text { motivation to train and compete at } \\
\text { the highest level }(\mathrm{n}=40)^{*}\end{array}$ & $3(7.5)$ & $0(0)$ & $1(2.5)$ & $9(22.5)$ & $11(27.5)$ & $16(40)$ \\
\hline
\end{tabular}

$* P$ value $<.05$ 


\section{Discussion}

Our study aimed to understand NS usage among regular recreation gym users in Kampala city of Uganda. Over half of gym users who used NS played either netball, soccer, athletics, or weightlifting. A significant number of gym users who utilized NSs reported not playing sports $(46.7 \%, \mathrm{p}=.017)$. Male and female gym users both reported that their primary source for NS products was either a retail store or pharmacy. Most supplements were consumed for endurance, increased training load, increased strength, health reasons and motivation to compete at higher levels. Overall, the study respondents, who were a representative sample of gym users in Kampala city, reported a high level of usage $(86.7 \%)$ of NS. Such prevalence rates are higher than those described in previous studies in urban cities. ${ }^{9,15}$ Selling NS in developing cities such as Kampala is a lucrative business for manufacturers of foreign products, which is a persuasive strategy to increase sales.

In developed countries, education, employment status and level of income are forms of socioeconomic status that are known determinants for the usage of $\mathrm{NS}^{16-18}$ whereas cultural factors play a significant role in NS usage in developing countries such as Malawi. ${ }^{18}$ Higher levels of education have previously been associated with higher NS usage. ${ }^{19-21}$ Although the majority of participants in this study reported having attained some form of secondary school education, it is possible that those with a higher education level greatly value the role of nutrition in their overall health. ${ }^{22}$ In the neighboring country of Kenya, income and education have also been attributed to higher usage of dietary supplements, ${ }^{23}$ although the levels of education among teachers in Kenyan secondary schools were not significantly related to supplement consumption. ${ }^{24}$ In other African countries, such as Malawi, cultural factors may also play a significant role in NS usage. ${ }^{18}$ 
Furthermore, the majority of participants in this study reported having received NS products from retail area sources in urban areas of Kampala. In Uganda, most of these retail areas include urban pharmacies, shops and small clinics. Although most pharmacies in Uganda have been largely approved by the National Drug Authority, ${ }^{25} \mathrm{a}$ few instances of operational irregularities stemming from the utilization of unqualified attendants have been reported in some areas of Uganda, ${ }^{25}$ suggesting a possibility of similar instances in cities such as Kampala. A recent study on the existence of falsified medical products in various African countries revealed that the available evidence on falsified and substandard medical products in Uganda's pharmaceutical wholesalers might be misleading given that the evidence was not collected from the informal sector but rather from a wholesaler, rendering that evidence inadmissible. ${ }^{26}$ However, there has been the implementation of strict policies and the enforcement of laws against the sale of counterfeit products in Uganda and neighboring Kenya, as cited by a recent study indicating a shift to online markets, which lack relevant legislation. ${ }^{27}$

Energy drinks (26.7\%), vitamins (26.7\%) and protein supplements (22.2\%) were the most consumed types of supplements among professional gym users in Kampala city, whereas energy drinks (62.2\%) and herbal products (46.7\%) were the most widely used NS types among nonprofessional gym users in Kampala city. The reported impact of energy drinks on cardiorespiratory fitness could have been the main motivating factor for the widespread use of energy drinks. ${ }^{28} \mathrm{~A}$ large proportion of respondents in our study indicated weightlifting as a main professional sport played. Likewise, supplement usage among weightlifters in the current study was high, corroborating earlier findings. ${ }^{8}$ Overall, the results of this study partially agree with those of previous studies on nutrition supplement usage in other cities. ${ }^{9}$ 
Our study reveals the occurrence of multiple supplement consumption patterns of professional and nonprofessional gym users in Kampala city. Such patterns of multiple usages of NS have been similarly reported in the U.S., where vitamins/minerals, herbs, and other specific supplements were concurrently used daily. ${ }^{29}$ However, multiple supplement usage might be detrimental for consumers in Uganda, especially given the lack of individual primary physicians for many of the people in Uganda, ${ }^{30}$ compared to their counterparts in the U.S., thus putting consumers in Uganda at a risk for serious adverse effects arising from high intakes.

As was reported in an earlier study, ${ }^{8}$ the perception of the usage of NS by gym users in the current study ranged from increasing strength, improving endurance and making one healthier. Although the majority of participants in our study were male at $61.3 \%$, with female participants accounting for only $38.7 \%$, previous studies have revealed varying gender

compositions of their studies. ${ }^{31-34}$ Our participants asserted that their perceptions and motivation for consuming NS were related to the desire for increased strength, increased endurance, and harnessing of health benefits. Future studies could explore gender-based perceptions and motivation for using NS in Kampala.

\section{Conclusion}

Our study is the first to evaluate the usage of NS among gym users in Kampala city in Uganda. The results indicate that there is a very high prevalence of NS usage among gym users, most of whom indicated the role of trainers, coaches and retail stores or pharmacies in the acquisition and distribution of NS. Energy drinks and herbal supplements were among the most preferred types of supplements among professional and nonprofessional gym users. Perceptions and motivations for NS usage were related to performance enhancement aspects of endurance and strength rather 
than as a doping agent. Other motivations were related to the users' perception of acquiring health benefits with the use of supplements.

\section{Perspectives}

The findings of this current study are vital in guiding interventions and education programs that address community usage of NS in Kampala city. Furthermore, the heightened usage of NS underscores the immediate necessity for coaches and trainer certification and continuing education in nutrition and wellness. There is a need for strict enforcement by the National Drug Authority to ensure the sale of safe nutrition supplement products in the retail outlets of Kampala city. Although enforceable policies could act as a deterrent to the possible sale and eventual consumption of expired and counterfeit products, it is highly recommended that legislation on the sale of products via online markets be introduced.

\section{List of abbreviations}

NS Nutritional supplements

NSPS Nutritional Supplement Perception Scale

PEAS Performance Enhancement Attitudes Scale

RDA Recommended Dietary Allowance

\section{DECLARATIONS}

\section{Ethics approval and consent to participate}

This research was carried out in compliance with the Helsinki Declaration, and approval to conduct the study was obtained from the Institutional Review Board of the School of Biomedical Sciences (SBS-REC); protocol number: SBS 601. Additionally, the study was registered by the Uganda National Council of Science and Technology; Protocol Number: SS 5026. Written informed consent was obtained from all study participants.

\section{Consent for publication}


Not applicable

\section{Availability of data and material}

The datasets used and/or analyzed during the current study are available from the corresponding author on reasonable request.

\section{Competing interests}

The authors declare that they have no competing interests.

\section{Funding}

None

\section{Author's contributions}

HM \& TM contributed to the study conceptualization, data collection, data analysis, manuscript writing and revision. SL, RZ \& RM contributed to manuscript writing and revision. All authors read and approved the final manuscript.

\section{Acknowledgements}

The authors would like to express their sincere gratitude to the gym participants who rendered their time to contribute to this study. We would also like to thank our research assistants Samuel Mugaya, Henry Bakumpe and Alice Namatovu for their unwavering support during the data collection.

\section{ORCID}

Timothy Makubuya: https://orcid.org/0000-0002-9236-0876

Haruna Muwonge: https://orcid.org/0000-0003-3964-2169

\section{References}

1. https://www.worldometers.info/world-population/uganda-population/

2. Abdul Nasser Ssemugabi DB. Using supplements to enhance the game. The daily Monitor. (2015, 25th May 2015).Retrieved from http://www.monitor.co.ug/Magazines/Health-\%2D-Living/Using-supplements-toenhance-the-game/-/689846/2728180/-/y8i9dx/-/index.html 
3. Kitutu FE. Uganda Medicines Transparency Alliance. Screening Drug Quality Project Report. Kampala, Uganda: Uganda Medicines Transparency Alliance; 2015.

4. National Research Council (US) Subcommittee on the Tenth Edition of the Recommended Dietary Allowances. Recommended Dietary Allowances: 10th Edition. Washington (DC): National Academies Press (US); 1989. 2, Definition and Applications. Available from: https://www.ncbi.nlm.nih.gov/books/NBK234926/

5. Schroder U. "Health effects of nutritional supplements," in Health and Doping Risks of Nutritional Supplements and Social Drugs, W. Schanzer, F. T. Delbeke, A. Deligiannis, G. Gmeiner, R. Maughan, and J. Mester, Eds., pp. 11-15, Sport and Buch StrauB, Cologne, Germany, 2002.

6. Huang SH, Johnson K, Pipe AL. The use of dietary supplements and medications by Canadian athletes at the Atlanta and Sydney olympic games. Clinical Journal of Sport Medicine, 2006, 16 (1); 27-33.

7. Tsitsimpikou, C., Chrisostomou, N., Papalexis, P., Tsarouhas, K., Tsatsakis, A., \& Jamurtas, A. The use of nutritional supplements among recreational athletes in Athens, Greece. International Journal of Sport Nutrition and Exercise Metabolism, 2011, 21(5), 377-384. https://doi.org/10.1123/ijsnem.21.5.377

8. Muwonge H, Zavuga R, Kabenge PA, Makubuya T. Nutritional supplement practices of professional Ugandan athletes: a cross-sectional study. J Int Soc Sports Nutr. 2017;14:41.

9. El Khoury D, Antoine-Jonville S. Intake of Nutritional Supplements among People Exercising in Gyms in Beirut City. J Nutr Metab. 2012;2012:703490. doi:10.1155/2012/703490

10. Morrison LJ, Gizis F, Shorter B: Prevalent use of dietary supplements among people who exercise at a commercial gym. Int J Sport Nutr Exerc Metab 2004, 14(4):481-92.

11. Solheim SA, Nordsborg NB, Ritz C, Berget J, Kristensen AH, Morkeberg J. Use of nutritional supplements by Danish elite athletes and fitness customers. Scand J Med Sci Sports. 2016; doi:10.1111/sms.12704

12. Oliver AJS, Leon MTM, Hernandez EJ. Statistical analysis of the consumption of nutritional and dietary supplements in gyms," Archivos Latinoamericanos de Nutricion, 2008; 58(3); 221-227.

13. Petróczi A, Aidman E. Measuring explicit attitude toward doping: review of the psychometric properties of the performance enhancement attitude scale. Psychol Sport Exercise. 2009;10(3):390-396. doi: 10.1016/j.psychsport.2008.11.001

14. Schwenk TL, Costley CD. When food becomes a drug: non-anabolic nutritional supplement use in athletes," American Journal of Sports Medicine, 2002; 30(6): 907-916.

15. Goston JL, Correia MI. Intake of nutritional supplements among people exercising in gyms and influencing factors. Nutrition. 2010;26(6):604-611.

16. Kofoed CL, Christensen J, Dragsted LO, Tjonneland A, Roswall N. Determinants of dietary supplement use-healthy individuals use dietary supplements. Br J Nutr 2015;113:1993-2000.

17. Sicińska E, Pietruszka B, Januszko O, Kałuża J. Different Socio-Demographic and Lifestyle Factors Can Determine the Dietary Supplement Use in Children and Adolescents in Central-Eastern Poland. Nutrients. 2019;11(3):658. 
18. Williams L, Semu L, Behague D, Sibale C, France C. A qualitative study of constraints to reducing iron deficiency and anaemia in women of reproductive age in Thyolo district, Malawi. Arlington, VA: MotherCare, John Snow Inc. 1996

19. Foote JA, Murphy SP, Wilkens LR, Hankin JH, Henderson BE, Kolonel LN. Factors associated with dietary supplement use among healthy adults of five ethnicities: the Multiethnic Cohort Study. Am J Epidemiol. 2003;157(10):888-897. doi:10.1093/aje/kwg072

20. Nayge RM, Reed DB. Factors associated with the intake of dietary supplements. Fam Econ Nutr Rev. 1999;12:43-48.

21. Dickinson A, MacKay D. Health habits and other characteristics of dietary supplement users: a review. Nutr J. 2014;13:14.

22. Buettner C MK, Gardiner P, Davis RB, Phillips RS, Mittleman MA. Herbal supplement use and blood lead levels of United States adults. J Gen Intern Med. 2009: 24: 11751182.

23. Wachira, Susan W. Knowledge and usage of dietary supplements, and dietary patterns of gym users in Nairobi. Tesis de Magister, University of Nairobi, Kenia, 2011. [Online]. Available: http://erepository.uonbi.ac.ke/handle/11295/25939

24. Gikwa J, Njogu E, Kimiywe J. Use of Dietary Supplements among Teachers in Public Secondary Schools in Kikuyu, Kiambu County, Kenya: A Cross Sectional Analytical Study. International Journal of Health Sciences \& Research. 2019, 9(9): 146-153

25. Mayora C, Kitutu F, Kandala N, Ekirapa-Kiracho E, Peterson S, Wamani H. Private retail drug ships: what they are, how they operate, and implications for health care delivery in rural Uganda. BMC Health Services Research. 2018; 18(532).

26. Petersen A, Held N, Heide L; Difäm-EPN Minilab Survey Group. Surveillance for falsified and substandard medicines in Africa and Asia by local organizations using the low-cost GPHF Minilab. PLoS One. 2017;12(9):e0184165. doi:10.1371/journal.pone.0184165

27. Lee KS, Yee SM, Zaidi STR, Patel RP, Yang Q, Al-Worafi YM, Ming LC. Combating Sale of Counterfeit and Falsified Medicines Online: A Losing Battle. Front. Pharmacol. 2017, 8, 268.

28. Rahnama N., Gaeini AA, \& Kazemi F. The effectiveness of two energy drinks on selected indices of maximal cardiorespiratory fitness and blood lactate levels in male athletes. Journal of research in medical sciences. 2010; 15(3), 127-132

29. Block G, Jensen CD, Norkus EP, et al. Usage patterns, health, and nutritional status of long-term multiple dietary supplement users: a cross-sectional study. Nutr J. 2007;6:30.

30. Ssenyonga R. Family Medicine may be helpful in improving health care delivery in subSaharan Africa. Afr Health Sci. 2007;7(2):120-121

31. Alowais MA, Selim MA. Knowledge, attitude, and practices regarding dietary supplements in Saudi Arabia. J Family Med Prim Care. 2019;8:365-72.

32. Sharma A, Shalini A, Ashok M. Knowledge, attitude and practices related to dietary supplements and micronutrients in health sciences students. J Clin Diagn Res. 2014;8:10-3.

33. Braun M, Venter I. Use of dietary supplements, and awareness and knowledge of the recommended fruit and vegetable intakes and consumption of health food store customers 
in the Cape Town city bowl. South African Journal of Clinical Nutrition. 2008;21:32330.

34. Shahwan M, Zain-AlAbdin SM. Knowledge and practice of dietary supplement and micronutrients among medical students at Ajman University. J Pharm Sci Res. 2018;10:85-90. 